\title{
Phylogenetic and Biogeographic Analysis of Ordovician Homalonotid Trilobites
}

\author{
Curtis R. Congreve* and Bruce S. Lieberman
}

\author{
Department of Geology and Natural History Museum and Biodiversity Research Center, University of Kansas; \\ Lawrence, Kansas. USA
}

\begin{abstract}
Cladistic parsimony analysis of the trilobite family Homalonotidae Chapman 1980 produced a hypothesis of relatedness for the group. The family consists of three monophyletic subfamilies, one containing Trimerus Green 1832, Platycoryphe Foerste 1919, and Brongniartella Reed 1918; one containing Plaesiacomia Hawle and Corda 1847 and Colpocoryphe Novák in Perer 1918; and one containing Eohomalonotus Reed 1918 and Calymenella Bergeron 1890. All genera are monophyletic, except Brongniartella, which is paraphyletic; as it was originally defined it "gives rise" to Trimerus and Platycoryphe.

A modified Brooks Parsimony Analysis using the phylogentic hypothesis illuminates patterns of biogeography, in particular, vicariance and geodispersal of homalonotids, during the late Ordovician. The analysis yields three major conclusions about homalonotid biogeography: homalonotids originated in Gondwana; Avalonia and Laurentia were close enough during the late Ordovician to exchange taxa, especially when sea level rose sufficiently; and long distance dispersal events occurred between Armorica and Florida, and also between Arabia and a joined Laurentia-Avalonia.
\end{abstract}

\section{INTRODUCTION}

The Homalonotidae Chapman 1890 [1] is a distinctive group of relatively large Ordovician-Devonian trilobites. They are not especially diverse, although they are common in nearshore environments. However, because of their shovel-like cephalon and tendency towards effacement, they have received some interest among paleontologists in general and trilobite workers in particular (Fig. 1). There have been debates about taxonomy of the Homalonotidae. These are caused in part by the group's close evolutionary affinity to its sister taxon, Calymenidae Burmeister 1843 [2] (see Edgecombe [3] for a phylogeny of trilobite families to support this relationship). In particular, this has caused paleontologists to suggest different family-level assignments for some genera (see [4-9] for varying opinions on homalonotid classification). Also, the Ordovician homalonotids are rather distinct, such that there is a morphological discontinuity between these and the more derived Silurian and Devonian forms [7]. Here we revisit the issue of homalonotid taxonomy using a phylogenetic analysis. Our focus is primarily on Ordovician homalonotids since these are most critical from the perspective of reconstructing taxonomic patterns in the group because they are phylogenetically basal, and also this study may provide information on the number of taxa affected by the end Orodovician mass extinction. On the whole, our reconstructed phylogenetic patterns correspond most closely to Thomas' [7] taxonomy of the family. Further, we use the phylogenetic hypothesis to reconstruct biogeographic patterns in the group by conducting a modified Brooks Parsimony Analysis [10-11]. The biogeographic analysis makes it possible to consider the role of biogeography in the end Orodovician mass extinction.

\footnotetext{
*Address correspondence to this author at the Department of Geology and Natural History Museum and Biodiversity Research Center, University of Kansas; Lawrence, Kansas. USA; E-mail: oldjack327@yahoo.com
}

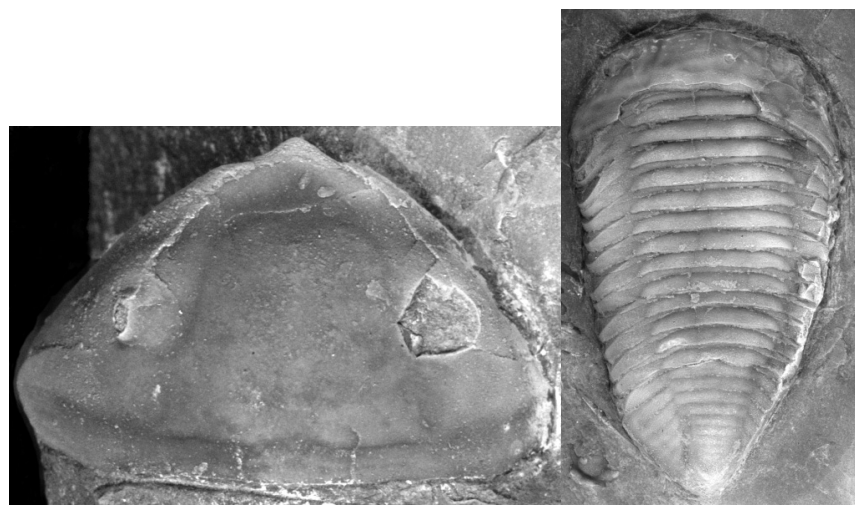

Fig. (1). Trimerus delphinocephalus cephalon 2.4x magnification (left) YPM 204412 and thorax and pygidium 1.2x (right) YPM 204408. Middle Silurian, Clinton Group, Rochester Shale. Collected in Lockport, New York.

\section{Materials Analyzed}

Specimens from the Yale Peabody Museum (YPM) YPM 7449A, 7449B, 33872, 33870, 204407, 204410, 6575, 204408, 204412, and 204411 and Harvard's Museum of Comparative Zoology (MCZ) MCZ 190759, 190778, 190828, and 190832 were used in our analysis. For key references on homalonotids, see $[4,7,8,12-17]$.

\section{Methods}

Morphological terminology follows [18].

Taxa Analyzed- Sixteen taxa were considered in this phylogenetic analysis. Neseuretus Hicks, 1873 [19] was used as the outgroup; it is widely considered to be a basal calymenid. For instance, see [7, 8, 20] though see [21-22] for a contrary viewpoint. The taxa analyzed in the ingroup had been originally assigned to Plaesiacomia Hawle and Corda, 1847 [23], Trimerus Green, 1832 [24], Platycoryphe Foerste, 
1919 [25], Calymenella Bergeron, 1890 [26], Brongniartella Reed, 1918 [27], Eohomalonotus Reed, 1918 [27], and Colpocoryphe Novák in Perer, 1918 [28]. The hierarchical placement of several of these genera has been a matter of contention. Although traditionally placed with Homalonotidae, Henry [8] had argued that Colpocoryphe belonged in Calymenidae based on hypostomal structures that suggested the genus was closely related to Neseuretus. He also argued that Platycoryphe and Calymenella should be removed from Homalonotidae and placed in Calymenidae, primarily based on thoracic characters [9]. However, we include these three genera in Homalonotidae based on characters of the cephalon, glabella, and pygidium that we discuss more fully below.

Character Analysis- The characters used for this phylogenetic analysis come from the dorsal side of the mineralized exoskeleton. Hypostomal characters were not included because the hypostome is rarely preserved in homalonotids and for too many of the taxa analyzed incomplete information was available. The characters are listed below in approximate order from anterior to posterior position on the organism.

1. anterior margin outline --- dorsal view (convex $=0$ / not convex $=1$ )

2. preglabellar field expansion (sag.) --- dorsal view (roughly twice length of LO [sag.] $=0 /$ roughly the length of L0 [sag.] = 1)

3. cephalic outline --- dorsal view (lanceolate $=0$ [anterior margin width $>$ width of L0 and lateral margin weakly convex] / subovate $=1$ [anterior margin width $<$ width of L0 and lateral margin strongly convex] / triangular $=2$ [anterior margin width $\leq$ width of L0 and lateral margin weakly convex])

4. glabellar furrows (encroaching sagittal axis of glabella $=0 /$ restricted to lateral margins or indistinct $=$ 1)

5. anterior margin of glabella --- dorsal view (not strongly convex $=0 /$ strongly convex $=1$ )

6. inflation of anterior margin of cephalon --- dorsolateral view (inflated $=0 /$ not inflated $=1$ )

7. ala distinctness --- dorsal view (distinct $=0 /$ indistinct or absent $=1$ ). The ala is a semicircular lobe adjacent to the basal glabella outlined by a furrow of variable depth.

8. glabella convex on entire lateral margin --- dorsal view (present $=0 /$ absent $=1$ )

9. glabella expands laterally in the medial section of L1 to form a bell shape --- dorsal view (absent $=0 /$ present $=1$ )

10. glabella posterior margin --- dorsal view (strongly convex $=0 /$ not strongly convex $=1$ )

11. shape of posterior part of fixigenae --- dorsal view (subangular $=0 /$ rounded $=1$ )

12. posterior fixigenal angle --- dorsal view, relative to transverse line $\left(30-40^{\circ}=0 />55^{\circ}=1\right)$
13. lateral processes on axial rings $($ present $=0 /$ absent $=$ 1)

14. cephalon lateral convexity --- lateral view $($ distinct $=$ $0 /$ indistinct $=1$ )

15. occipital ring (thickest medially, with anteriorly directed lateral wing-like processes $=0 /$ uniform thickness, posteriorly curved, with indistinct or absent lateral wing-like processes $=1 /$ uniform thickness or widest medially, but parallel to thoracic axis, with anteriorly directed lateral wing-like processes indistinct or absent $=2$ ) *the specimen used to code Plaesiacomia exul did not possess a complete occipital ring so the coding for this taxa was accomplished by extrapolation, using what was left of the structure.

16. glabellar furrows --- dorsal view (deep $=0 /$ shallow or absent $=1$ )

17. pygidial axis shape --- dorsal view (funnel-shaped $=0$ / ovate $=1$ )

18. swollen tubercle on pygidial axial terminus --- dorsal view $($ present $=0 /$ absent $=1)$

19. posterior pygidial pleurae $($ distinct $=0 /$ indistinct $=$ 1)

20. pygidial outline --- dorsal view (conical $=0 /$ subconical $=1$ )

21. number of pygidial axial furrows $(\geq 5=0 / \leq 3=1)$

22. posterior pygidial margin --- dorsal view (convex $=0$ / concave $=1$ )

23. a coaptive pygidial groove, parallel to lateral pygidial margins that connects to anterior cephalic margin during enrollment --- dorsal view $($ absent $=0 /$ present $=$ 1)

24. $\quad$ pygidial lateral convexity --- dorsal view $($ distinct $=0$ $/$ indistinct $=1$ )

25. pygidial dorsal convexity --- lateral view (pronounced $=0 /$ not pronounced $=1$ )

26. lateral expansion of the last axial segment of the pygidial axis --- lateral view $($ absent $=0 /$ present $=1)$

Phylogenetic Analysis- The data (Table 1) were analyzed using PAUP 4.0 [29]. A branch and bound search was used to determine the most parsimonious tree for this data matrix. All multistate characters were treated as unordered. Bootstrap and Jackknife statistical tests, as well as a test of Bremer [30] support, were performed to assess the statistical strength of our results. The Bootstrap and Jackknife tests were performed using PAUP [29] and were analyzed heuristically with 1,000 replicates; five most parsimonious trees were sampled at each replication. A Bayesian analysis using MrBayes v.3.1.2 [31] was also performed on the data, with the $n s t=6$ and rates=invgamma. This allows rates of change to vary between and within transformation series. The mcmc went through 10,000,000 generations, sampling every 1000 generations. All matrix data were compiled into Nexus files using Macclade v.4.08 [32] and Mesquite v.2.01 [33] and trees were generated using FigTree v.1.1.2 [34].

Specific Taxa Analyzed-Plaesiacomia exul (Whittington 1953) [35], P. vacuvertis Thomas 1977 [7], P. oehlerti (Ker- 
forne 1900) [36], Colpocoryphe arago (Rouault 1849) [37], C. roualti Henry 1970 [38], Calymenella boisselli Bergeron 1890 [26], C. alcantarae Hammann \& Henry 1978 [39], Brongniartella bisulcata (M'Coy 1851, ex Salter, MS.) [40], B. trentonensis (Simpson 1890) (YPM 7449A and 7449B, MCZ 190828 and 190832) [41], Trimerus delphinocephalus (Green 1832) [24] (YPM 33872, 33870, 204407, 204410, 6575, 204408, 204412, and 204411), Eohomalonotus sdzuyi Hammann \& Henry 1978 [39], Platycoryphe dyaulax Thomas 1977 [7], P. dentata Dean 1961 [17], P. christyi (Hall 1860) [42], and $P$. vulcani (Murchison 1839) [43] for a total of fifteen ingroup taxa. Neseuretus vaningeni Dean \& Martin 1978 [18], was chosen as the outgroup for the analysis because it is a well-preserved, complete specimen of Neseuretus from the lower Ordovician of eastern Newfoundland.

\section{Results}

Analysis results and comparison between phylogenetic methods- The parsimony analysis yielded the single most parsimonious tree with a length of 54, a CI of 0.5185 , and an RI of 0.7615 (Fig. 2). The Bayesian analysis also yielded a tree, although none of the posterior probabilities were significant with 95\% confidence (Fig. 3). The nodes with the highest posterior probabilities in the Bayesian analysis also had the highest Jackknife and Bootstrap values in the parsimony analysis. High Bremer support values, however, did not strongly correlate with high posterior probabilities; for instance, the node that defines a monophyletic group with Trimerus and Platycoryphe has a Bremer support value of 2, but a posterior probability of only $51 \%$. Focusing on the topologies of both trees, the relationships implied by the parsimony tree basically concur with those implied from the Bayesian derived tree, with two exceptions. In particular, the Bayesian analysis predicted Brongniartella was monophyletic, while the parsimony analysis indicated Brongniartella was paraphyletic (in essence "giving rise" to both Trimerus and Platycoryphe). Further, the parsimony analysis indicated that Eohomalonotus grouped with Calymenella, while the Bayesian analysis placed both taxa in a polytomy. For the purposes of taxonomy and biogeography, we will be using the tree generated from the parsimony analysis as our phylogenetic hypothesis. The Bayesian tree can be treated as another means of gauging support for different aspects of the tree, in addition to the Jackknife/Bootstrap and Bremer support methods.

We chose to include members of the genus Colpocoryphe in our analysis despite Henry's [8] claim that the genus belongs to the Calymenidae based on hypostomal characters. We found that Colpocoryphe grouped with the ingroup and close to Plaesiacomia, which challenges aspects of Henry's [8] hypothesis; however, we were unable to include hypostomal characters given their typically poor and incomplete state of preservation. In order to test how strongly the presence of Colpocoryphe affected the tree topology, all members of the genus were removed and the data matrix was analyzed again. The absence of Colpocoryphe had no affect on the topology. Henry [8] also argued Calymenella was a calymenid. Again, our phylogenetic results do not support this contention, but to test the effect including this taxon had on our result, we removed Calymenella from the analysis: the overall topology did not change.
Systematic Paleontology- According to our analysis Calymenella, Colpocoryphe, Plaesiacomia and Platycoryphe are monophyletic. Therefore, we do not redefine these taxa. Brongniartella as traditionally conceived is paraphyletic. Since bisulcata is the type species, we suggest that it be placed in a monotypic genus Brongniartella. Using the convention established by Wiley [44], we place trentonensis in "Brongniartella", with the quote marks denoting the group's paraphyly. (We are hesitant to create a monotypic genus for trentonensis simply because we have not included every known taxa of "Brongniartella" and thus do not know the entire structure of this paraphyletic group.) It was impossible to determine if Eohomalonotus or Trimerus as traditionally conceived were monophyletic since we only included one species of each of these taxa, and our primary emphasis was on Ordovician and Early Silurian exponents of the homalonotids.

The data suggests three larger monophyletic groups (subfamilies) within the Homalonotidae: one consisting of Trimerus-"Brongniartella"-Platycoryphe; another consisting of Colpocoryphe-Plaesiacomia; and the third consisting of Eohomalonotus-Calymenella. These subfamilies on the whole match those Thomas [7] identified. In particular, Thomas [7] grouped Trimerus, Brongniartella, and Platycoryphe within the Homalonotinae; he grouped Colpocoryphe and Plaesiacomia within the Colpocoryphinae Hupé, 1955 [45]; and he grouped Calymenella and Eohomalonotus within the Eohomalonotinae Hupé, 1953 [22]. Since our data supports Thomas's [7] revision of these subfamilies, no new redefinition of these groups is required.

\section{Genus BRONGNIARTELLA Reed 1918}

TYPE SPECIES: Homalonotus bisulcata M'Coy 1851, ex Salter, MS [40].

\section{DISCUSSION}

Since the genus Brongniartella has been shown to be paraphyletic, we redefine the genus into a monotypic genus that includes only its type species, bisulcata, and refer the other species considered to the paraphyletic "Brongniartella". For an in-depth diagnosis of Brongniartella bisulcata, refer to Dean [18].

Biogeography Analysis: Methods- We used our phylogeny to perform a biogeographic analysis using a modified version of Brooks parsimony analysis (BPA). This method is described in detail in $[10,11,47]$, although some brief discussion is provided here, and has been used successfully to investigate biogeographic patterns in a variety of groups, including trilobites, e.g. $[10,11,48-53]$. Modified BPA makes it possible to detect patterns of geodispersal and vicariance. First, we created an area cladogram by replacing the names of the end member taxa with the geographic areas in which these taxa were found (Fig. 4). The areas used in the analysis were Avalonia (Newfoundland and Great Britain), Eastern Laurentia (the United States), Armorica (France and Spain), Arabia (Saudi Arabia), and Florida (Fig. 5) These areas were defined on the basis of geological evidence and because they contain large numbers of endemic taxa; in effect this follows the area descriptions and designations of [54-58]. Next, the geographic locations for the ancestral nodes of the area cladogram were optimized using a modified version of the Fitch [59] parsimony algorithm. Then, the area cladogram was used to generate two matrices, one to 
Table 1. Character Matrix

\begin{tabular}{|c|c|c|c|c|c|c|c|c|c|c|c|c|c|c|c|c|c|c|c|c|c|c|c|c|c|c|}
\hline Taxon/Characters & 1 & 2 & 3 & 4 & 5 & 6 & 7 & 8 & 9 & 10 & 11 & 12 & 13 & 14 & 15 & 16 & 17 & 18 & 19 & 20 & 21 & 22 & 23 & 24 & 25 & 26 \\
\hline Neseuretus & 0 & 0 & 0 & 0 & 0 & 0 & 0 & 0 & 0 & 0 & 0 & 0 & 0 & 0 & 0 & 0 & 0 & 0 & 0 & 0 & 0 & 0 & 0 & 0 & 0 & 0 \\
\hline delphinocephalus & 0 & 0 & 2 & 1 & 0 & 1 & 1 & 1 & 0 & 1 & 1 & 1 & 1 & 1 & 2 & 1 & 0 & 1 & 0 & 0 & 0 & 0 & 0 & 1 & 1 & 0 \\
\hline dyaulax & 1 & 1 & 2 & 1 & 0 & 1 & 0 & 1 & 0 & 1 & 1 & 1 & 1 & 1 & 2 & 1 & 0 & 1 & 0 & 1 & 0 & 0 & 0 & 1 & 1 & 0 \\
\hline exul & 1 & 1 & 1 & 1 & 0 & 1 & 1 & 0 & 0 & 1 & 1 & 0 & 1 & 1 & 1 & 1 & 0 & 1 & 1 & 0 & $?$ & 1 & $?$ & $?$ & $?$ & 0 \\
\hline dentata & 0 & 1 & 2 & 0 & 0 & 1 & 0 & 0 & 0 & 1 & 1 & 1 & 1 & 1 & 2 & 1 & 0 & 0 & 0 & 1 & 0 & 0 & 0 & 1 & 0 & 0 \\
\hline christyi & 1 & 1 & 2 & 0 & 0 & 1 & 0 & 0 & 0 & 0 & 1 & 1 & 1 & 1 & 2 & 1 & 0 & 1 & 0 & 1 & 0 & 0 & 0 & 1 & 0 & 0 \\
\hline vulcani & 1 & 1 & 2 & 0 & 0 & 1 & 0 & 1 & 0 & 1 & 1 & 1 & 1 & 1 & 2 & 1 & 0 & 1 & 0 & 1 & 0 & 0 & 0 & 1 & 1 & 0 \\
\hline bisulcata & 0 & 1 & 0 & 1 & 0 & 1 & 1 & 1 & 0 & 1 & 0 & 1 & 1 & 0 & 2 & 1 & 0 & $?$ & 0 & 0 & 0 & 0 & 0 & 0 & 0 & 0 \\
\hline trentonenesis & 0 & 1 & 0 & 1 & 0 & 1 & 1 & 1 & 0 & 1 & 0 & 1 & 1 & 1 & 2 & 1 & 0 & 0 & 0 & 0 & 0 & 0 & 0 & 1 & 0 & 0 \\
\hline arago & 1 & 1 & 1 & 0 & 1 & 1 & 1 & 0 & 0 & 0 & 0 & 0 & 0 & 0 & 0 & 0 & 0 & 0 & 1 & 0 & 0 & 1 & 1 & 0 & 0 & 1 \\
\hline vacuvertis & 1 & 1 & 1 & 1 & 1 & 1 & 1 & 0 & 0 & 1 & 1 & 0 & 1 & 0 & 1 & 1 & 1 & 1 & 1 & 0 & 1 & 1 & 1 & 0 & 0 & 0 \\
\hline oehlerti & 1 & 1 & 1 & 1 & 0 & 1 & 1 & 0 & 0 & 1 & 1 & 0 & 1 & 0 & 1 & 1 & 1 & 1 & 1 & 0 & 1 & 1 & 1 & 0 & 0 & 0 \\
\hline rouaulti & 1 & 1 & 1 & 0 & 0 & 1 & 1 & 1 & 0 & 0 & 0 & 0 & 0 & 0 & 0 & 0 & 0 & 0 & 1 & 0 & 0 & 1 & 1 & 0 & 0 & 1 \\
\hline boisselli & 0 & 0 & 2 & 0 & 0 & 0 & 0 & 0 & 1 & 0 & 0 & 0 & $?$ & $?$ & 0 & 1 & 1 & $?$ & 0 & 1 & 0 & 0 & 0 & 0 & 0 & 0 \\
\hline alcantarae & 1 & 0 & 2 & 0 & 1 & 0 & 0 & 0 & 1 & 0 & 0 & 0 & 0 & $?$ & 0 & 1 & 1 & $?$ & 0 & 1 & 0 & 0 & 0 & 0 & 0 & 0 \\
\hline sdzuyi & 0 & 0 & 0 & 0 & 1 & $?$ & $?$ & 0 & 1 & 0 & 1 & 0 & $?$ & $?$ & 0 & 1 & 0 & $?$ & 0 & 0 & 0 & 1 & 0 & 0 & 0 & 0 \\
\hline
\end{tabular}

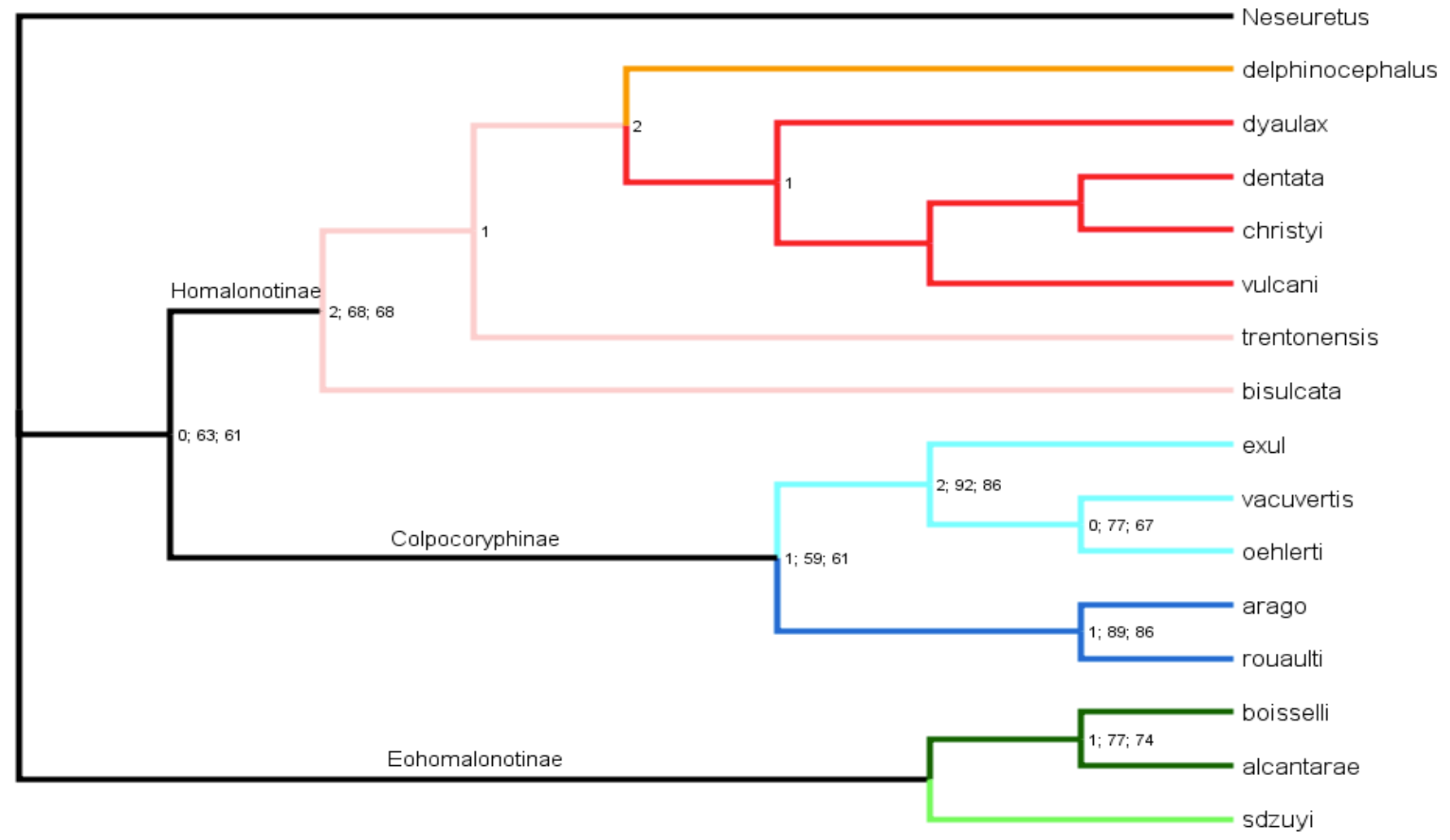

Fig. (2). Cladogram of the results from the parsimony analysis. Tree graphics generated using FigTree v.1.1.2 [34]. The stems that connect to an end member species have been color coded based on the genus they were traditionally assigned to, where Platycoryphe is red, Trimerus is orange, Brongniartella is pink, Plaesiacomia is light blue, Colpocoryphe is dark blue, Calymenella is dark green, and Eohamalonotus is light green. The values at the nodes are the results from the statistical tests. The first number is the Bremer Support value, the second is the Bootstrap value, and the third is the Jackknife value. Trees for the Bootstrap and Jackknife analyzes were generated using $50 \%$ majority rule consensus. 


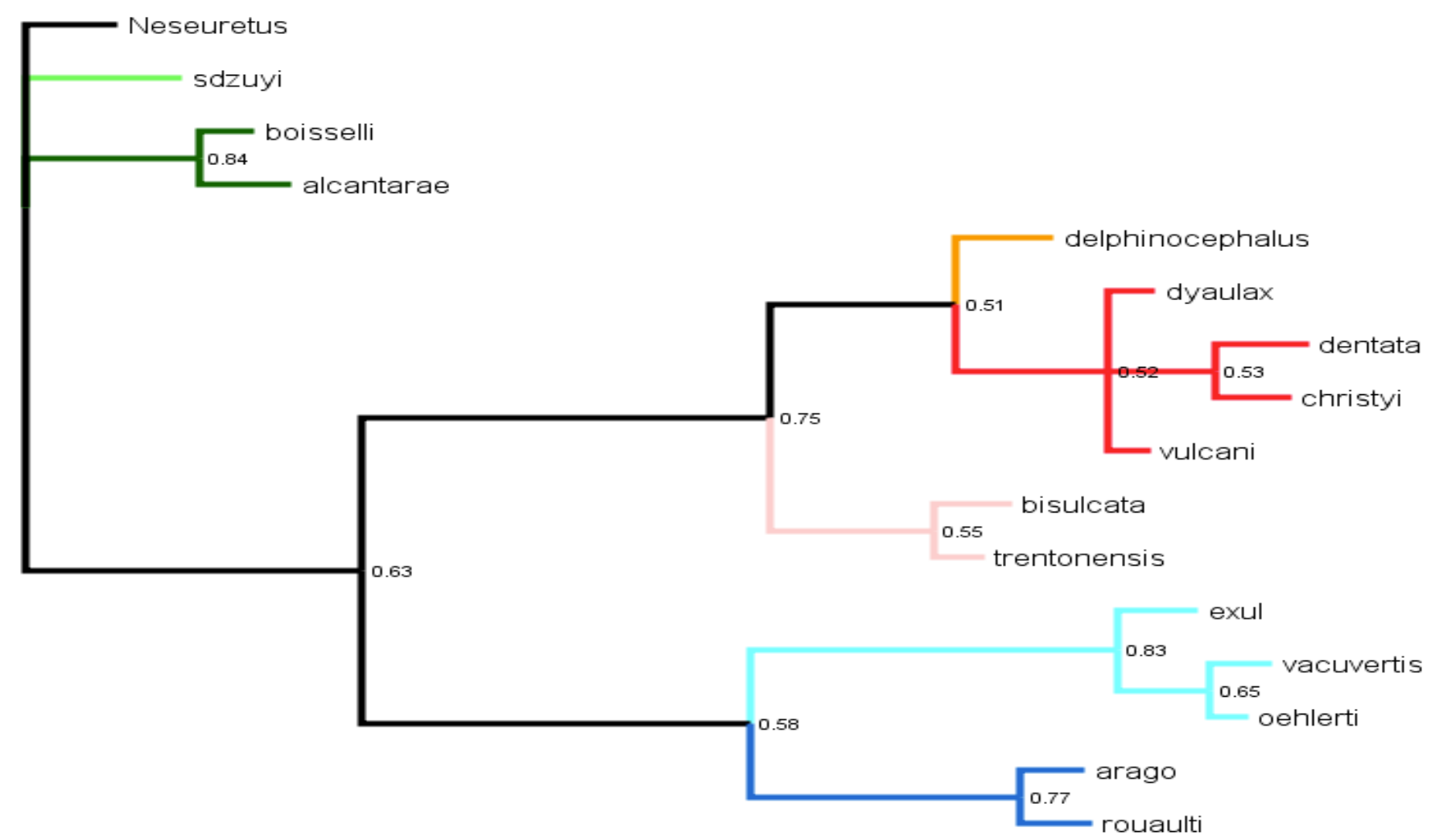

Fig. (3). Phylogram of the results from the Bayesian analysis. Tree graphics generated using FigTree v.1.1.2 [34]. The stems that connect to an end member species have been color coded based on the genus they were traditionally assigned to, where Platycoryphe is red, Trimerus is orange, Brongniartella is pink, Plaesiacomia is light blue, Colpocoryphe is dark blue, Calymenella is dark green, and Eohamalonotus is light green. The values at the nodes are the posterior probabilities for those nodes.

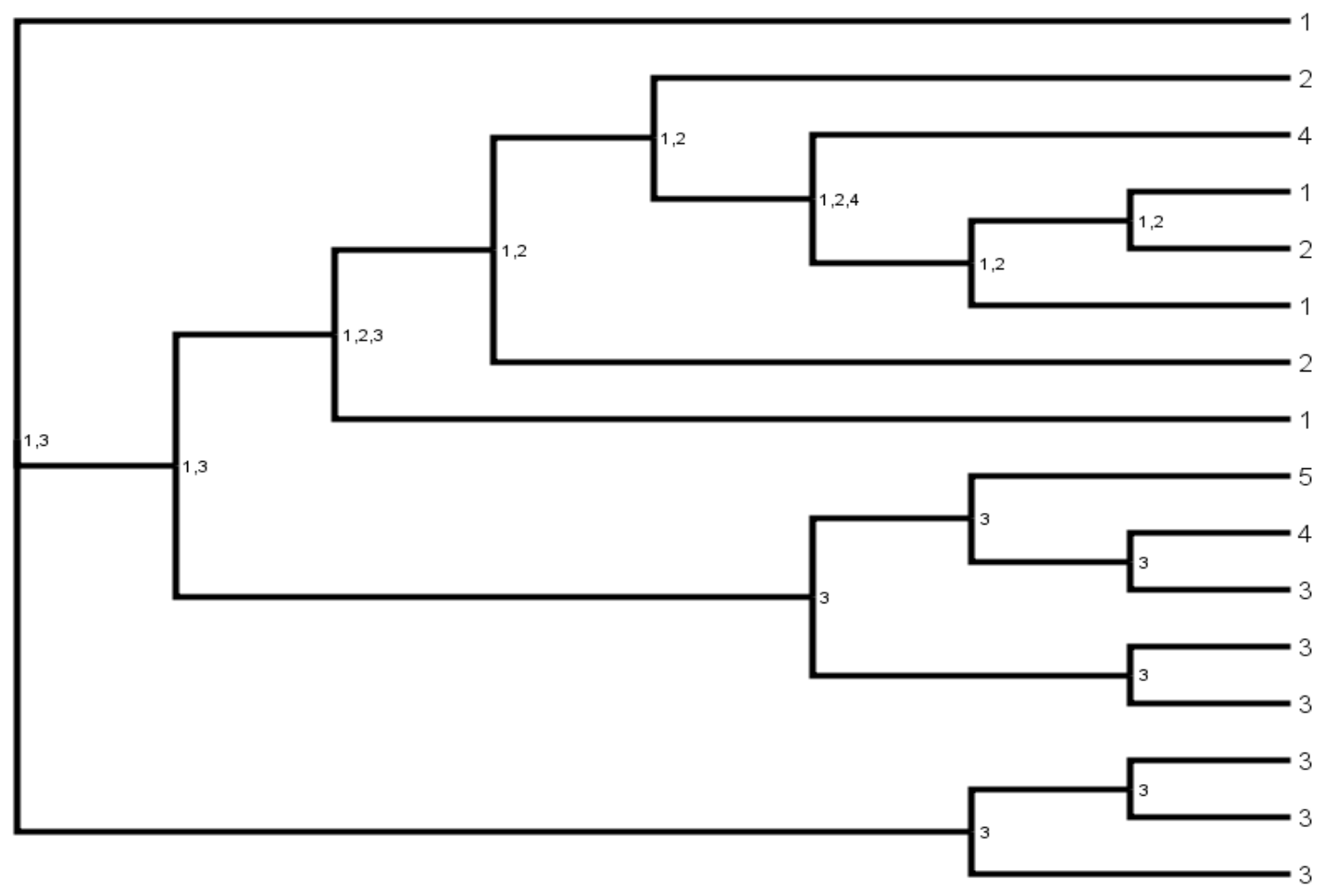

Fig. (4). Area cladogram. Tree graphics generated using FigTree v.1.1.2 [34]. The numbers code for the locations in which the taxa were found, where 1 = Avalonia, $2=\mathrm{E}$. Laurentia, $3=$ Armorica, $4=$ Arabia, and $5=$ Florida. The numbers at the nodes are the optimized locations of the ancestral taxa. 


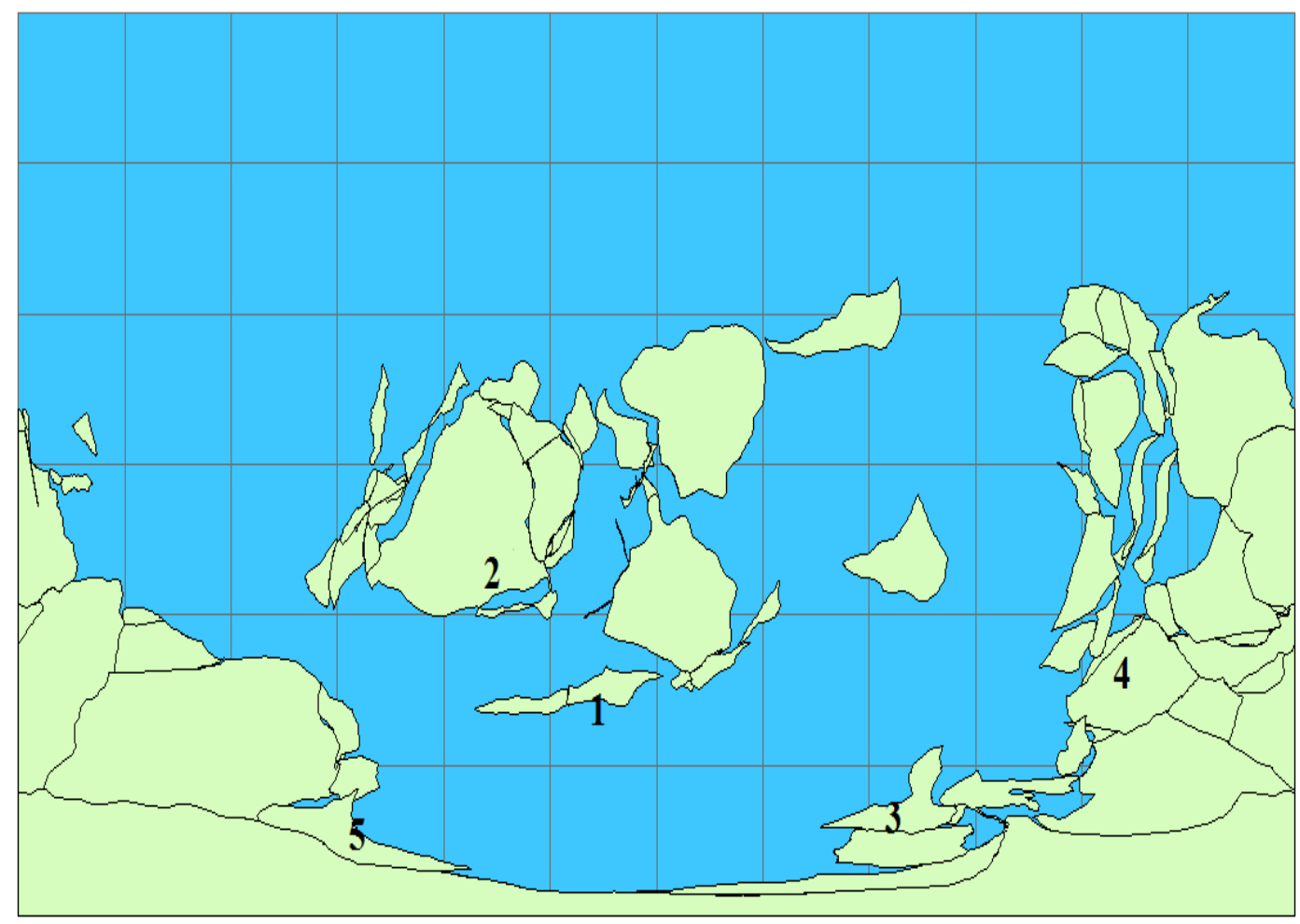

453.5Ma (Caradocian); ScoteseAcademicModel; C. R. Scotese, $\odot$ 2007, PALEOMAP Project

Fig. (5). Map of the late Ordovician (Caradoc) world generated with ArcView 9.2 and PaleoGIS [46]. The biogeographic areas used in this analysis are numbered $1=$ Avalonia, $2=\mathrm{E}$. Laurentia, $3=$ Armorica, $4=$ Arabia, and $5=$ Florida.

code for patterns of vicariance and the other to code for patterns of geodispersal. The former provides information about the relative time that barriers formed, isolating regions and their respective biotas; the latter provides information about the relative time that barriers fell, allowing biotas to congruently expand their range $[10,11,47]$. Each matrix was then analyzed using an exhaustive search on PAUP 4.0 [29]. The results are presented in Fig. (6). All matrix data was compiled into Nexus files using Mesquite v.2.01 [33] and trees were generated using FigTree v.1.1.2 [34].

Results of the biogeographic analysis- The geodispersal analysis yielded the single most parsimonious tree of 37 steps. The tree suggests the most recent barriers to fall were those between E. Laurentia and Avalonia and those between Florida and Armorica. The next most recent barriers to fall were those between a combined E. Laurentia-Avalonia and Arabia. Finally, the oldest barriers were those between E. Laurentia-Avalonia-Arabia and Florida-Armorica. The vicariance analysis yielded four most parsimonious trees of 47 steps. A strict consensus of these four trees has only one resolved node: Avalonia and E. Laurentia, suggesting some vicariance between trilobites from these respective regions.

We also used the test of Hillis [60], the $g_{1}$ statistic, to see whether the results from our analysis differ from those produced using random data. Our results differ from those generated using random data at the .01 level. Bootstrap, Jackknife, and Bremer support values were calculated for both trees. In the geodispersal tree, the node uniting Avalonia and
Laurentia was most robust, with Bremer, Bootstrap, and Jackknife values of $2,91 \%$, and $87 \%$ respectively. In the vicariance tree, the node uniting Avalonia and Laurentia had Bremer, Bootstrap, and Jackknife values of 3, 95\%, and 92\% respectively.

Interpretation of biogeographic results and discussionThe close relationship between E. Laurentia and Avalonia is replicated in both the vicariance and geodispersal trees (Fig. 4). This suggests that the processes producing vicariance and geodispersal between these areas were similar, implicating cyclical processes, likely sea-level rise and fall, played an important role in generating the biogeographic patterns $[10$, $11,47,49]$. In effect, this result largely matches paleomagnetic and tectonic evidence which indicates that Avalonia rifted from Gondwana during the early-mid Ordovician and began drifting towards Laurentia and Baltica; during the early Silurian, Avalonia and Baltica joined together to form Balonia; and this in turn collided with Laurentia during the Taconic orogeny [55, 58, 61-63]. Probably by the late Ordovician the Iapetus Ocean was effectively closed [61]. Our data suggest that either Laurentia and Avalonia were geographically close enough to each other during the late Ordovician to directly exchange taxa when sea level rose sufficiently, or they were indirectly exchanging taxa, with Baltica acting as an intermediary.

Our results, in particular, the geodispersal tree (Fig. 6), also indicate a close biogeographic relationship between Avalonia-Laurentia and Arabia. When the patterns implied 


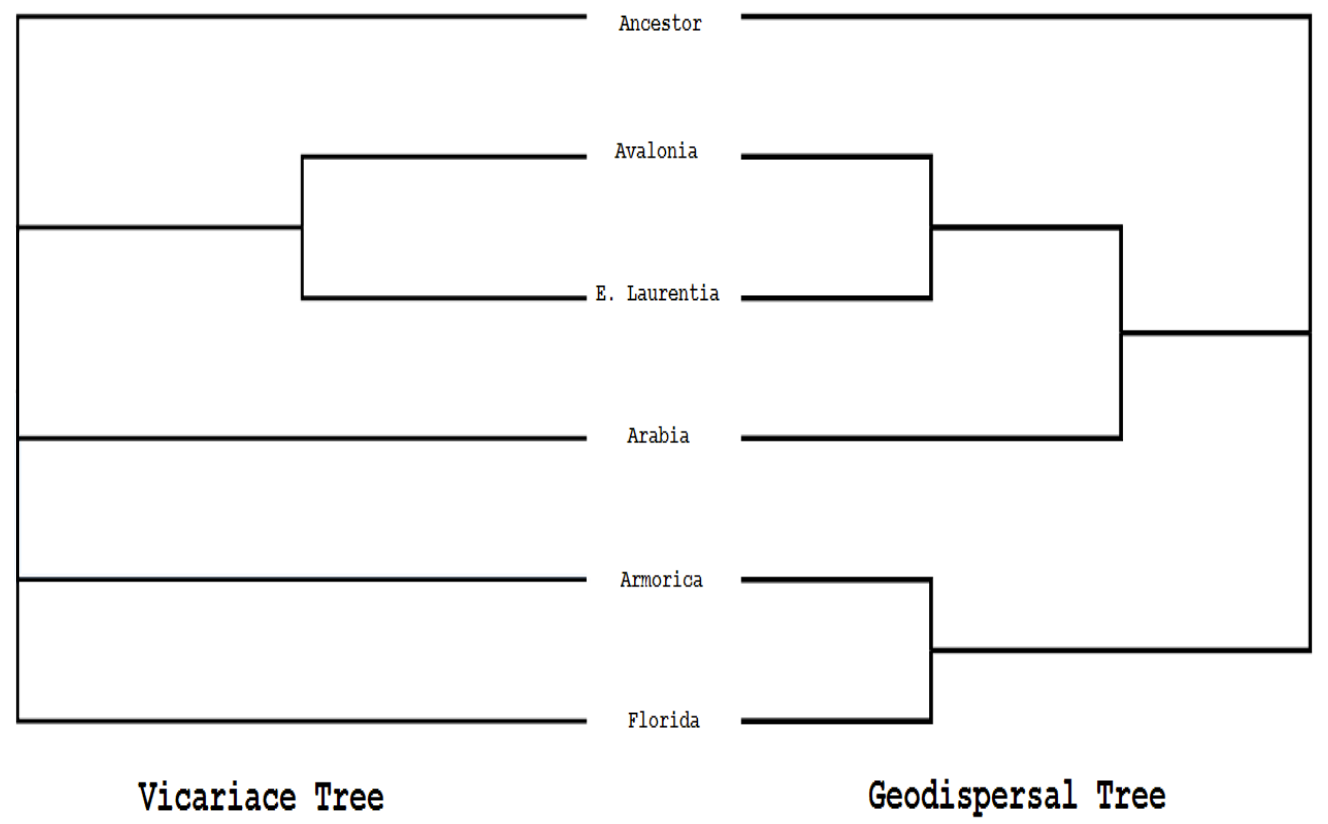

Fig. (6). On the right the most parsimonious geo-dispersal tree and on the left the strict consensus of four most parsimonious vicariance trees.

by the vicariance and geodispersal trees differ, as is the case with this aspect of the biogeographic results, it could be due to a tectonic collision or a chance long distance dispersal event $[10,11,47,49]$. Given that there is no substantial tectonic evidence linking these regions, the dispersal between Avalonia-Laurentia and Arabia was unlikely to have been facilitated by a tectonic event, and instead may have been due to chance long distance dispersal between these regions. This dispersal could have been facilitated by a planktonic larval stage, however homalonotids are presumed to have had benthic larvae [64]. Dispersal also could have been facilitated by chains of island arcs that allowed organisms to island-hop to Gondwana.

The geodispersal tree also shows a grouping of Armorica and Florida (Fig. 6). During the late Ordovician, paleomagnetic and tectonic evidence suggests that Armorica had rifted away from the main continent of Gondwana [58, 61]. It is possible the rifted Armorica could have moved close enough to Florida to exchange taxa during this time period. However, since the vicariance tree does not record this rifting event, we cannot be sure if the separation of Armorica from Gondwana had the primary affect on the biogeographic patterns of homalonotids at the time, or instead these patterns were due to chance long distance dispersal. Furthermore, again there is no strong tectonic evidence to support a collision between Florida and Armorica.

Our area cladogram (Fig. 4) also indicates that the homalonotids most likely originated in Gondwana, during a time when Avalonia was still connected to the main continent. This is because the area of the ancestral node of all homalonotids consists of a united Avalonia and Armorica. If we track patterns of biogeographic change up the tree, it appears that Avalonia then rifted from Gondwana, carrying with it a homalonotid fauna that diversified in Avalonia and later dispersed from Avalonia into Laurentia. Our data indicates Laurentian homalonotids have a close evolutionary relationship with Avalonian forms. Indeed, all Laurentian and Avalonian homalonotids group in a single subfamily (Figs. 2, 4). Ultimately, the movement of homalonotids into Laurentia appears to have had an important effect on macroevolutionary patterns in the group, as the group underwent substantial subsequent diversification after it entered that region.

\section{ACKNOWLEDGEMENTS}

We would like to thank Susan Butts from the YPM and Jessica Cundiff and Fred Collier from the MCZ for providing access to study material that was vital for the completion of this study, and also for loaning material used for study. We would also like to thank two anonymous reviewers and the editors for comments on an earlier version of this manuscript. Financial support for this research was provided by NSF DEB-0716162 and NASA Astrobiology NNG04G M41G.

\section{REFERENCES}

[1] Chapman EJ. Some remarks on the clasification of the trilobites as influenced by stratigraphical relations; with outline of a new grouping of these forms. Trans R Soc Can 1890; 7: 113-20.

[2] Burmeister H. Die Organisation der trilobiten. Berlin: Georg Reimer; 1843.

[3] Edgecombe GE. In: Novacek MJ, Wheeler QD, Eds. Extinction and Phylogeny. New York. Columbia University Press. 1992; 14477.

[4] Whittard WF. The Ordovician trilobites of the Shelve Inlier, Shropshire Part V. Palaeontogr Soc Monogr 1960; 63-167. pls. 223.

[5] Vanek J. New species of the suborder Calymenina Swinnerton, 1915 (Trilobita) from the Barrandian area. Sb Geol Ved Praha (Pal) 1965; 6: 21-38

[6] Whttington HB. Trilobites of the henllan ash, arenig series, merioneth. Bull Br Mus Nat Hist A 1966; 11: 489-505.

[7] Thomas AT. Classification and phylogeny of homalonotid trilobites. Palaeontology 1977; 20: 159-78.

[8] Henry JL. Ordovician Calymenina (Trilobita). Geol Soc Mag 1980; 117: 351-62.

[9] Henry JL. Classification de quelques Calymenina (Trilobita) Ordoviciens; Calymenidae ou Homalonotidae? Geobios 1996; 29(3): $331-40$. 
[10] Lieberman BS, Eldredge N. Trilobite biogeography in the middle devonian: geological processes and analytical methods. Paleobiology 1996; 22: 66-79.

[11] Lieberman BS. Paleobiogeography: Using Fossils to Study Global Change, Plate Tectonics, and Evolution. New York: Kluwer Academic; 2000.

[12] Whittington H. Platycoryphe, an Ordovician homalonotid trilobite. J Paleontol 1965; 39(3): 487-91.

[13] Whittington H. Trilobites. Rochester (NY): Boydell Press; 1992.

[14] Whiteley TE, Kloc GJ, Brett CE. Trilobites of New York. Ithica: Cornell University Press; 2002.

[15] Hammann W. Calymenacea (Trilobita) aus dem Ordovizium von Spanien; inhre Biostratigraphie, Ökologie und Systematik. Senckenber Naturforsh Ges 1983; 543: 1-177.

[16] Dean WT. The Ordovician trilobite faunas of South Shropshire, II. Bull Br Mus Nat Hist (Geo) 1961; 5: 311-58.

[17] Dean WT, Marin F. Lower Ordovician acritarchs and trilobites from Bell Island, Eastern Newfoundland. Geol Surv Can Bull 1978; 284: 1-35.

[18] Whittington HB, Chatterton BDE, Speyer SE, et al. In: Kaesler RL, Ed. Treatise on invertebrate paleontology; Part O; Arthropoda 1; Trilobita, revised. Lawrence (KS): The University of Kansas Press and the Geological Society of America. 1997; 1-554.

[19] Hicks H. On the Tremadoc rocks in the neighbourhood of St. David's, South Wales and their fossil contents. Quart J Geol Soc 1872; 29: 616-47.

[20] Whittard WF. The Ordovician trilobites of the Shelve Inlier, Shropshire Part IV. Palaeontogr Soc Monogr 1959; 138-42.

[21] Sdzuy K. In: Moore RC, Ed. Treatise on Invertebrate Paleontology; Arthropoda O(1). Lawrence (KS): The University of Kansas Press and the Geological Society of America. 1959; 454-5.

[22] Hupé P. In: Piveteau J, Ed. Traité de paleontology 3. Paris: Mason et Cie. 1953; 44-246.

[23] Hawle I, Corda A. Prodrom einer Monographie der bohmischen Trilobiten. Koeniglichen Boehmischen Gesellschaft der Wissenschaften, Abhandlungen 1847; 5: 1-176.

[24] Green J. A monograph of the trilobites of North America with coloured models of the speices. Philadelphia: Joseph Brano; 1832.

[25] Foerste A. Silurian fossils from Ohio, with notes on related species from other horizons. Ohio J Sci 1919; 19: 367-404.

[26] Bergeron J. Sur une forme nouvelle de Trilobite de la famille des Calymenidae (genre Calymenella). Bull Soc Géol France 1890; 3(18): 356-71.

[27] Reed F. Notes on the genus Homalonotus. Geol Mag 1918; 5: $263-$ 76.

[28] Novák O. In: Perner J, Ed. Trilobiten der Zone D-dly von Prag und Umgebung. Palaeontographica Bohemica 1918; 9: 1-55.

[29] Swofford D. PAUP v. 4.0. [computer program] 1998. Available from: http://paup.csit.fsu.edu/

[30] Bremer $\mathrm{K}$. The limits of amino acid sequence data in angiosperm phylogenetic reconstruction. Evolution 1988; 42: 795-803.

[31] Huelsenbeck J, Ronquist F. MrBayes v.3.1.2. [computer program] 2005. Available from: http://mrbayes.csit.fsu.edu /

[32] Maddison D, Maddison W. MacClade v.4.08. [computer program] 2005. Available from: http://macclade.org/

[33] Maddison D, Maddison W. Mesquite v.2.01 [computer program] 2007. Available from: http://mesquiteproject.org/

[34] Rambaut A. FigTree v.1.1.2. [computer program] 2008. Available from: http://tree.bio.ed.ac.uk/software/figtree/

[35] Whittington HB. A new ordovician trilobite from Florida. Breviora 1953; 17: 1-6.

[36] Kerforne F. Description de trois nouveaux Trilobites de l’Ordovicien de Bretagne. Bull Soc Géol France 1900; 28(3): 34488.

[37] Rouault M. Mémoire: $1^{\circ}$ sur la composition du test des Trilobites; $2^{\circ}$ sur les changements de forme dûs a des causes accidentelles, ce qui a pu permettre de confondre des espèces différentes. Bull Soc Géol France 1849; 6: 67-89.
[38] Henry JL. Quelques calymenacea (Trilobites) de l'ordovicien de bretagne. Ann Paléont Invertéb 1970; 56: 1-27.

[39] Hammann W, Henry JL. Quelques espèces de Calymenella, Eohomalonotus et Kerfornella (Trilobita, Ptychopariida) de l'Ordovicien du Massif Armoricain et de la Péninsule Ibérique. Senck Leth 1978; 59: 401-29.

[40] Sedgwick A, M'Coy F. A synopsis of the classification of the British Palaeozoic rocks, with a systematic description of the British Paleozoic fossils in the geological museum of the University of Cambridge. 1851; 168

[41] Simpson GB. Descriptions of new species of fossils from the clinton, lower helderberg, chemung, and waverly groups, found in the collections of the geological survey of Pennsylvania. Trans Am Philosophical Soc 1890; 16 (3): 460

[42] Hall J. New species of fossils from the Hudson-River Group of Ohio, and other western states. $13^{\text {th }}$ Ann Rep New York State Cabinet Nat Hist 1860; 119-21

[43] Murchison RI. The silurian system founded on geological researches in the counties of Salop, Hereford, Radnor, Montgomery, Caermarthen, Brecon, Pembroke, Monmouth, Gloucester, Worcester, and Stafford; with descriptions of the coal-fields and overlying formations. London: John Murray; 1839.

[44] Wiley EO. The evolutionary species concept reconsidered. Syst Zool 1978; 27(1): 17-26.

[45] Hupé P. Classification des trilobites. Annis Paléont 1955; 41: 91325 .

[46] Scotese CR. PaleoGIS. [computer program] 2007. Available from: http://www.scotese.com/software.htm

[47] Lieberman BS. Biogeography of the Trilobita during the Cambrian radiation; deducing geological processes from trilobite evolution. In: Lane PD, Siveter DJ, Fortey RA, Eds. Trilobites and their relatives. Special Papers in Palaeontology 2003; 70: 59-72.

[48] Hembree DI. Amphisbaenian paleobiogeography: evidence of vicariance and geodispersal patterns. Palaeogeogra Palaeoclimatol Palaeoecol 2006; 235: 334-48.

[49] Rode AL, Lieberman BS. Paleobiogeographic patterns in the Middle and Late Devonian emphasizing Laurentia. Palaeogeogr Palaeoclimatol Palaeoecol 2005; 222: 272-84.

[50] Lee S-b, Lee D-C, Choi DK. Cambrian-Ordovician trilobite family Missisquoiidae Hupé, 1955: Systematic revision and palaeogeographical considerations based on cladistic analysis. Palaeogeogr Palaeoclimatol Palaeoecol 2008; 260: 315-41.

[51] Brooks DR, Thorson TB, Mayes MA. Freshwater stingrays (Potamotrygonidae) and their helminth parasites: testing hypotheses of evolution and coevolution. In: Funk VA, Brooks DR, Eds. Advances in Cladistics: Proceedings of the First Meeting of the Willi Hennig Society. Bronx, New York Botanical Garden. 1981; 147 75.

[52] Brooks DR. Historical ecology: a new approach to studying the evolution of ecological associations. Ann Mo Bot Garden 1985; 72: $660-80$

[53] Wiley EO. Parsimony analysis and vicariance biogeography. Syst Zool 1988; 37: 271-90.

[54] Fortey RA, Cocks LRM. The early Palaeozoic of the North Atlantic region as a test case for the use of fossils in continental reconstruction. Tectonophysics 1992; 206: 147-58.

[55] Scotese CR, McKerrow WS. In: Barnes CR, Williams SH, Eds. Geological Survey of Canada: Paper 90-9. 1991; 271-282.

[56] Harper DAT. Ordovician provincial signals from AppalachianCaledonian terranes. Terra Nova 1992; 4: 204-9.

[57] Torsvik TH, Tait J, Moralev VM, et al. Ordovician palaeogeography of Siberia and adjacent continents. J Geol Soc, Lond 1995; 152: $279-87$

[58] Torsvik TH, Smethurst MA, Meert JG, et al. Continental break-up and collision in the Neoproterozoic and Palaeozoic- A tale of Baltica and Laurentia. Earth-Science Rev 1996; 40: 229-58.

[59] Fitch WM. Toward defining the course of evolution: minimum change for a specific taxa topology. Syst Zool 1971; 20: 406-16.

[60] Hillis DM. Discriminating between phylogenetic signal and random noise in DNA sequences. In: Miyamoto MM, Cracraft J, Eds. Phylogenetic analysis of DNA sequences. 1991; 278-94. 
[61] Trench A, Torsvik TH. The closure of the Iapetus ocean and tornquist sea: new palaeomagnetic constraints. J Geol Soc, Lond 1992; 149: 867-70.

[62] Soper NJ, Strachan RA, Holdsworth RE, et al. Sinistral transpression and the silurian closure of iapetus. J Geol Soc, Lond 1992; 46: 175-92.
[63] McKerrow WS. Wenlock to givetian deformation in the British isles and the Canadian appalachians. In: Harris AL, Fettes DJ, Eds. The Caledonian-Appalachian Orogen. Geological Society, Special Publication. London 1988; vol. 38: pp. 405-12.

[64] Speyer SE, Chatterton BDE. Trilobite larvae and larval ecology. Hist Biol 1989; 3: 27-60.

Received: April 8, 2008

(C) Congreve and Lieberman; Licensee Bentham Open.

This is an open access article licensed under the terms of the Creative Commons Attribution Non-Commercial License (http://creativecommons.org/licenses/by$\mathrm{nc} / 3.0 /$ ) which permits unrestricted, non-commercial use, distribution and reproduction in any medium, provided the work is properly cited. 